\title{
Hubungan Antara Minat Belajar Dengan Prestasi Belajar Siswa Dalam Bidang Studi Ski
}

\author{
Oleh: \\ * Mohammad Firdaus \\ Email: mohammadfirdaus292@gmail.com \\ STIS SAYYID AL-MALIKI Bondowoso, Indonesia
}

\begin{abstract}
Abstrak
Pendidikan pada dasarnya adalah usaha untuk menumbuhkembangkan potensi sumber daya manusia peserta didik dengan cara mendorong dan memfasilitasi kegiatan belajar mereka. Banyak faktor yang dapat mempengaruhi prestasi belajar, salah satunya adalah minat belajar siswa terhadap bidang studi yang akan dipelajari. Dari deskripsi diatas nantinya akan diketahui apakah dengan adanya minat belajar siswa secara maksimal akan membuahkan hasil yang baik, ataukah tidak. Kemudian sejauh mana minat belajar siswa terhadap studi yang akan dipelajarinya.Dalam penelitian ini penulis mengumpulkan data tentang hubungan antara minat belajar dengan prestasi belajar siswa dalam bidang studi SKI di Madrasah Aliyah Miftahul Arifin Ranurejo Sumberanyar Banyuputih Situbondo, yaitu dengan mengambil 50 peserta didik Sebagai metode yang digunakan dalam penelitian ini adalah metode angket, dokumentasi dan observasi. Selanjutnya data tersebut di analisa dengan metode statistik, yaitu dengan menggunakan Rumus Korelasi Product Moment, Berdasarkan hasil analisa data dengan rumus tersebut, maka diperoleh hasil bahwa: "hubungan antara minat belajar dengan prestasi belajar siswa dalam bidang studi SKI di Madrasah Aliyah Miftahul Arifin Ranurejo Sumberanyar Banyuputih Situbondo Tahun Pelajaran 2014/2015 masih tergolong lemah atau rendah".Setelah diketahui rendahnya hubungan antara minat belajar dengan presatasi belajar siswa, maka penulis sarankan seyokyanya dalam pengajaran SKI semakin ditingkatkkan lagi agar hasilnya dapat lebih baik, sehingga pelajaran SKI sukses dengan mendapatkan hasil yang maksimal.
\end{abstract}

Keywords: Minat Belajar, Prestasi Belajar, studi SKI 



\section{Pendahuluan}

Pendidikan pada dasarnya adalah usaha untuk menumbuhkembangkan potensi sumber daya manusia peserta didik dengan cara mendorong dan memfasilitasi kegiatan belajar mereka. Secara detail, dalam undang-undang RI Nomor 20 Tahun 2003 tentang sistem pendidikan nasional Bab 1 Pasal 1 (1) pendidikan didefinisikan sebagai usaha sadar dan terencana untuk memujudkan suasana belajar dan proses belajar agar peserta didik secara aktif mengembangkan potensi dirinya untuk memiliki kekuatan spiritual keagamaan, pengendalian didri, kepribadian, kecerdasan, akhlak mulia, serta keterampilan yang diperlukan dirinya, masyarakat, bangsa dan negara. ${ }^{1}$.

Mengingat betapa pentingnya peranan pendidikan bagi kehidupan manusia, Allah memberikan derajat yang tinggi bagi orang yang mempunyai ilmu pengetahuan, sebagaimana firmanNya :

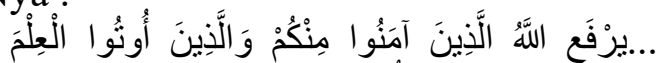

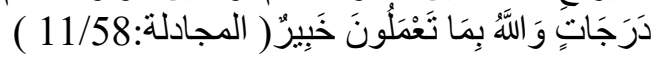
Artinya : "Allah akan meninggikan derajat orang - orang yang beriman dan orang-orang yang punya ilmu pengetahuan dari kamu sekalian dan allah maha mengetahui terhadap apa yang kamu sekalian lakukan".(Q.S Al Mujadalah:543/11). ${ }^{2}$

Sekolah sebagai bagian dari lembaga pendidikan haruslah mampu memaksimalkan sistem. Sistem yang ada di dalamnya, semisal: Guru, Siswa, metode pembelajaran dan lain lain. Sebab sekolah dalam hal ini haruslah menjadi miniatur masyarakat luas

\footnotetext{
${ }^{1}$ Muhibbin Syah, 2009. Psikologi Belajar. jakarta: Rajawali Press. Cet. ke-I, h.01.

2 Al-qur'an dan Terjemahanya, Departemen Agama Republik Indonesia, (Surabaya: Duta ilmu, 2015), h.543
}

sehingga siswa yang selesai dalam menempuh pendidikan sekolah akan dapat merekam pengetahuannya di dalam masyarakat.

Sedangkan kenyataan pada umumnya para siswa kurang berminat untuk menggali pengetahuannya sendiri, agak cenderung tergantung pada orang lain yang dalam hal ini adalah sosok seorang guru, sehingga siswa seakanakan mengibaratkan dirinya sebagai konsumen dan guru sebagai produsennya. Padahal siswa bisa saja memproduksi sendiri pengetahuannya, malah hal ini akan menghasilkan hasil yang maksimal karena siswa akan mendapatkan pengetahuannya tidak hanya ketika ada guru, tetapi di mana pun dan kapan pun ia berada selagi ia punya kemauan maka pengetahuan akan mudah diperoleh.

Sudah disadari baik oleh guru, siswa dan orang tua bahwa dalam belajar di sekolah, inteligensi (kemampuan intelektual) memerankan peranan yang penting, khususnya berpengaruh kuat terhadap tinggi rendahnya prestasi belajar siswa. Ini bermakna, semakin tinggi kemampuan inteligensi seorang siswa, maka semakin besar peluangnya untuk berprestasi. Sebaliknya, semakin rendah kemampuan inteligensi seorang siswa, maka semakin kecil peluangnya untuk memperoleh prestasi. ${ }^{3}$

Meskipun

peranan inteligensi sedemikian besar namun perlu diingat bahwa faktor-faktor lain pun tetap berpengaruh. Di antara faktor tersebut adalah "Minat".

Dalam hal ini minat adalah rasa suka dan keterikatan pada suatu hal atau aktfitas, tanpa ada yang menyuruh. Minat pada dasarnya adalah penerimaan akan suatu hubungan antara diri sendiri

\footnotetext{
${ }^{3}$ Muhibin Syah, Psikologi

Pendidikan dengan Pendekatan Baru,

(Bandung: Remaja Rosdakarya, 1997), h. 5
} 


\section{Hubungan Antara Minat Belajar Dengan Prestasi Belajar Siswa Dalam Bidang Studi Ski.......}

dengan sesuatu dilur diri. Semakin kuat atau dekat hubungan tersebut, semakin besar minatnya. Crow and Crow mengatakan bahwa minat berhubungan dengan gaya gerak yang mendorong seseorang untuk menghadapi atau berurusan dengan orang, benda, kegiatan, pengalaman yang dirangsang oleh kegiatan itu sendiri. Jadi minat dapat diekspresikan melalui pernyataan yang menunjukkan bahwa siswa lebih menyukai suatu hal dari pada lainnya, minat tidak dibawa sejak lahir, melainkan diperoleh kemudian. ${ }^{4}$

Dalam kegiatan belajar, minat mempunyai peranan yang sangat penting. Bila seorang siswa tidak memiliki minat dan perhatian yang besar terhadap objek yang dipelajari maka sulit diharapkan siswa tersebut akan tekun dan memperoleh hasil yang baik dari belajarnya. Sebaliknya, apabila siswa tersebut belajar dengan minat dan perhatian besar terhadap objek yang dipelajari, maka hasil yang diperoleh lebih baik. Seperti yang diungkapkan oleh Usman Efendi dan Juhaya S Praja bahwa "belajar dengan minat akan lebih baik daripada belajar tanpa minat". 5

Dari keterangan di atas, dapat dijelaskan bahwa siswa yang memiliki minat dengan siswa yang tidak memiliki minat dalam belajar akan terdapat perbedaan. Perbedaan tersebut tampak jelas dengan ketekunan yang terus menerus. Siswa yang memiliki minat maka ia akan terus tekun ketika belajar. Sedangkan siswa yang tidak memiliki minat walaupun ia mau untuk belajar

\footnotetext{
${ }^{4}$ Djaali, psikologi pendidikan, (Jakarta; Bumi Askara, 2012) h. 121

${ }^{5}$ Usman Efendi dan Juhaya S Praja,

Pengantar Psikologi, (Bandung: Angkasa,
}

1993) h. 122 akan tetapi ia tidak terus untuk tekun dalam belajar.

Begitu pula dalam proses belajar mengajar dalam mata pelajaran Sejarah Kebudayaan Islam. Tinggi rendahnya minat belajar siswa dalam mata pelajaran Sejarah Kebudayaan Islam tentunya akan memberikan pengaruh terhadap prestasi belajar yang akan dicapai oleh siswa.

Mata pelajaran Sejarah Kebudayaan Islam (SKI) merupakan mata pelajaran yang materinya berisikan peristiwa sejarah masa lalu, sehingga di sekolah guru sering terjebak menggunakan metode pelajaran yang digunakan lebih mengarah kepada metode ceramah atau bercerita saja. Padahal kedua metode tersebut dapat mendatangkan kebosanan siswa apabila guru yang memberikan materi tersebut tidak dapat menyesuaikan dengan kondisi atau keadaan siswa selain itu metode tersebut membuat siswa kurang kreatif menggunakan semua aspek kecerdasannya. Karena itu jika terjadi kebosanan pada siswa maka akan berpengaruh kepada minat siswa untuk mengikuti proses belajar. Demikian juga pembelajaran SKI yang seperti ini cukup kontektual dari sisi kebutuhan siswa untuk belajar mengembangkan dirinya sementara belajar berangkat dari kebutuhan siswa akan mudah membangkitkan minat siswa terhadap mata pelajaran tersebut, sehingga mereka dapat meraih prestasi yang lebih optimal ketika siswa tidak lagi merasa berminat untuk mengikuti pelajaran ini, tentunya hal ini akan memberikan dampak pada tinggi rendahnya prestasi pembelajaran siswa di bidang mata pelajaran SKI

Sehubungan dengan masalah tersebut dalam kesempatan ini penulis bermaksud mengkajinya dalam artikel dengan judul : 
Hubungan Antara Minat Belajar Dengan Prestasi Belajar Siswa Dalam Bidang Studi SKI di Madrasah Aliyah Miftahul Arifin Ranurejo Sumberanyar Banyuputih Situbondo Tahun Pelajaran 2014/2015.

Tujuan Adapun tujuan dalam penelitian ini adalah untuk membuktikan ada atau tidaknya hubungan antara minat belajar dengan prestasi belajar siswa dalam bidang studi SKI di Madrasah Aliyah Miftahul Arifin Ranurejo Sumberanyar Banyuputih Situbondo Tahun pelajaran 2014/2015

\section{Kajian Konseptual}

Beberapa istilah yang diperkirakan akan menimbulkan kekurangjelasan makna seandainya penegasan istilah tidak diberikan, antara lain:

1. Minat Belajar (variabel X)

Secara sederhana minat (interest)

berarti kecenderungan dan kegairahan yang besar terhadap sesuatu. Menurut Reber (1988), minat tidak termasuk istilah populer dalam psikologi karena ketergantungannya yang banyak pada faktor-faktor internal lainnya seperti: pemusatan penelitian, keingin tahuan, motivasi, dan kebutuhan.

Minat besar pengaruhnya terhadap belajar, karena bila bahan pelajaran yang dipelajari tidak sesuai dengan minat siswa, siswa tidak akan belajar dengan baik, karena tidak ada daya tarik baginya, ia segan-segan belajar untuk belajar, ia tidak memperoleh kepuasan dari pelajaran itu. Bahan pelajaran yang menarik minat belajar siswa, lebih mudah dipelajari dan disimpan, karena minat menambah kegiatan belajar. $^{6}$

2. Prestasi Belajar (variabel Y)

\footnotetext{
${ }^{6}$ Muhibbin Syah, 2013. Psikologi Belajar. Jakarta: PT. Raja Grafindo Persada, Cet. Ke-13, h.152
}

Prestasi merupakan hasil yang telah dicapai dari usaha yang telah dilakukan dan dikerjakan". Dalam definisi yang lebih singkat bahwa prestasi adalah "hasil yang telah di capai (dilakukan dan dikerjakan)". Senada dengan pengertian di atas, prestasi adalah "hasil yang telah di capai dari apa yang dikerjakan/ yang sudah diusahakan. ${ }^{7}$

3. Sejarah Kebudayaan

Islam adalah Salah satu bagian mata pelajaran Pendidikan Agama Islam yang diarahkan untuk menyiapkan peserta didik untuk mengenal, memahami, menghayati Sejarah Kebudayaan Islam, yang kemudian menjadi dasar pandangan hidupnya (way of life) melalui kegiatan bimbingan, pembelajaran, latihan, penggunaan pengalamanu dan pembiasaan". 8

\section{Metode}

Pendekatan penelitian ini menggunakan pendekatan kuantitatif. Metode penelitian kuantitatif dapat diartikan sebagai metode penelitian yang berlandaskan pada filsafat positivism, digunakan untuk meneliti pada populasi atau sampel tertentu, teknik pengambilan sampel pada umumnya dilakukan secara random, pengumpulan data menggunakan instrument penelitian, analisis data bersifat kuantitatif/statistik dengan tujuan untuk menguji hipotesis yang telah ditetapkan.

Dalam penelitian ini yang menjadi subyek penelitian adalah siswa Madrasah Aliyah Miftahul Arifin Ranurejo Sumberanyar Banyuputih

\footnotetext{
${ }^{7}$ Mahfudh Shahuddin, Pengantar Psikologi Pendidikan, (Surabaya: Bina Ilmu, 2004), Cet. Ke 1, h. 95

${ }^{8}$ Hurlock, Psikologi Perkembangan, (Jakarta: Erlangga, 2005), h. 422
} 


\section{Hubungan Antara Minat Belajar Dengan Prestasi Belajar Siswa Dalam Bidang Studi Ski.......}

Situbondo, yang terdiri dari dua kelas yaitu $\mathrm{X}$, dan XI, dengan jumlah keseluruhan 50 siswa.

Teknik analisis data dalam penelitian kuantitatif menggunakan statistik. Adapun rumus yang digunakan untuk menganalisa data hasil penelitian menggunakan product momen dengan Angka Kasar yang dipersiapkan terlebih dahulu, yang diarahkan kepada informasi-informasi untuk topik yang akan garap.

Metode pengumpulan data adalah cara bagaimana langkah yang sebaiknya untuk memperoleh data dalam penelitian.

Dan yang dilakukan dalam penelitian digunakan untuk menguji hipotesis atau menjawab pertanyaan yang telah dirumuskan. Karena data yang diperoleh akan dijadikan landasan dalam mengambil kesimpulan, data yang dikumpulkan haruslah data yang benar.

Dalam hal ini menggunakan metode :

1. Metode Angket

Koesioner

(angket)

merupakan teknik pengumpula data yang dilakukan dengan cara memberi seperangkat pertanyaan atau pertanyaan tertulis kepada responden untuk dijawab. ${ }^{9}$

$$
\text { Pendapat }
$$

tersebut memberikan gambaran, bahwa dalam proses pengumpulan data dengan metode angket dapat dilakukan dengan melalui proses pemberian sejumlah pertanyaan yang berhubungan dengan variabel penelitian, untuk dijawab oleh responden peneliti sesuai dengan kondisi yang sebenarnya. Metode ini

\footnotetext{
9 Sugiyono, 2008. Metode penelitian kuantitatif, kualitatif, dan R\&D, Bandung: Alfabeta, Cet. Ke-4, h.142
}

digunakan untuk memperoleh data tentang hubungan antara minat belajar dengan prestasi belajar.

Adapun angket yang di gunakan dalam penelitian ini adalah angket tertutup, yaitu angket yang menhendaki jawaban pendek atau jawabannya diberikan dengan membutuhkan tanda tertentu. ${ }^{10}$

2.Metode Dokumentasi

Metode Dokumenter adalah cara mengumpulkan data melalui peninggalan tertulis, seperti arsip-arsip dan termasuk juga buku-buku tentang pendapat, teori, dalil atau hukum-hukum dan lain-lain yang berhubungan dengan masalah penelitian. ${ }^{11}$

Metode ini digunakan untuk mencari data-data yang hanya dimiliki secara khusus oleh lembaga-lembaga yang dijadikan obyek penelitian misalnya: tentang sejarah singkat berdirinya lembaga tersebut dan sebagainya yang diperoleh dari dokumen-dokumen dan buku-buku yang ada.

Metode analisis data merupakan metode yang digunakan untuk menganalisa data yang diperoleh dari hasil penelitian. Metode analisi ini terdiri dari analisis statistik, untuk menganalisa data hubungan antara minat belajar dengan prestasi belajar siswa. Statistik yang dimaksud dalam mengumpulkan, meringkas dan menganalisa bahan yang berupa angka serta menarik kesimpulan dari hasil analisis.

Menurut Tulus Winarsunu Statistik adalah "Suatu metode dan

\footnotetext{
10 John. W. Best, 1982. Metodologi penelitian dan pendidikan, Surabaya: Usaha Offside Printing, h.176

11 Margono, 1997, Metodologi Penelitian Pendidikan, Jakarta: Rineka Cipta
} 
prosedur yang dilakukan untuk melakukan pengumpulan, pengolahan, penafsiran dan penarikan kesimpulan pada data hasil-hasil penelitian". ${ }^{12}$

Dari pendapat diatas statistik sangat berguna dalam pendidikan untuk mengelolah suatu data, karena penulis ingin mengetahui hubungan dari dua variabel, sehingga teknik yang dipakai adalah rumus product momen dengan rumus angka kasar.

Adapun rumusnya:

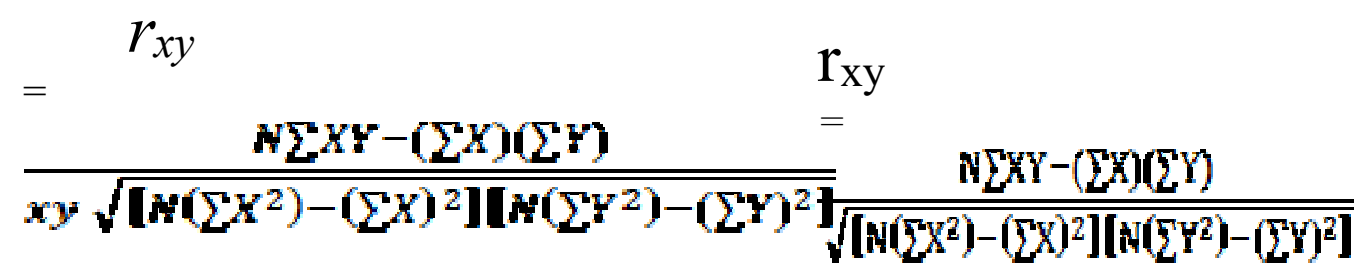

$\mathrm{XY}=$ Produk dari variabel minat dan prestasi

$\mathrm{N}=$ Jumlah individu yang diteliti.

\section{Pembahasan}

1. Teknik Analisa

Teknik analisa data yang digunakan dalam penelitian ini adalah teknik analis statistik. Teknik yang digunakan adalah korelasi product moment, dengan rumus :

keteranagn:

$$
\begin{aligned}
& \mathrm{X}=\text { Minat Belajar } \\
& \mathrm{Y}=\text { Prestasi Belajar } \\
& \text { rxy }=\text { Korelasi antara } \\
& \text { variabel } \mathrm{x} \text { dan } \mathrm{y} \\
& \Sigma \mathrm{X}=\text { Jumlah nilai variabel } \\
& \text { minat } \\
& \Sigma \mathrm{Y}=\text { Jumlah nilai variabel } \\
& \text { prestasi } \\
& \mathrm{X}^{2}=\text { Kuadrat dari } \\
& \text { variabel minat } \\
& \mathrm{X}^{2}=\text { Kuadrat dari } \\
& \text { variabel prestasi }
\end{aligned}
$$

12 Tulus Winarsunu, Statistik dalam Penelitian Psikologi dan Pendidikan, Malang: UMM press,h. 1
Dari rumus tersebut kemudian data yang terkumpul dihitung. Jika hasil perhitungan menunjukkan nilai lebih besar dari (r) tabel, maka berarti hipotesis penelitian yang diajukan diterima. Begitu pula sebaliknya, bila nilai dihitung lebih kecil dari (r) tabel pada tarif signifikan 5\% maka hasil hipotesis penelitian di tolak.

1. Kerja analisis dan pembuktian

$$
\text { Untuk menganalisis }
$$
penelitian, maka data yang telah terkumpul diorganisir. Langkah-langkah dalam mengorganisir penelitian ini adalah:

a. Menguadratkan data nilai hasil angket minat belajar yang diisi oleh siswa $\left(\mathrm{X}^{2}\right)$. 
Hubungan Antara Minat Belajar Dengan Prestasi Belajar Siswa Dalam Bidang Studi Ski.......

b. Mengkuadratkan data dari hasil prestasi belajar yang di ambil dari nilai raport siswa semester II $\left(\mathrm{Y}^{2}\right)$.

c. Mengkalikan data hasil nilai angket minat belajar dengan hasil raport semester II (XY)

d. Dengan mengorganisir data di atas, maka di peroleh data yang siap untuk dianalisa, seperti dalam tabel berikut:

Tabel 4.8

Perhitungan mencari koefisien korelasi

Nilai minat belajar $(\mathrm{X})$ dengan nilai prestasi belajar $(\mathrm{Y})$

\begin{tabular}{|c|c|c|c|c|c|}
\hline No & Sk & Sk & $\mathrm{X}^{2}$ & $\mathrm{Y}^{2}$ & $\mathrm{X}$ \\
Res & or & or & & & $\mathrm{Y}$ \\
pon & $\mathrm{Mi}$ & Pre & & & \\
den & nat & sta & & & \\
& Be & si & & & \\
& laj & Be & & & \\
& ar & laj & & & \\
& (X & ar & & & \\
& ) & (Y & & & \\
& & ) & & & \\
\hline 1 & 21 & 70 & 44 & 49 & 14 \\
& 21 & & 1 & 00 & 70 \\
\hline 2 & 21 & 60 & 44 & 36 & 12 \\
& & & 1 & 00 & 60 \\
\hline 3 & 22 & 70 & 48 & 49 & 15 \\
& 22 & & 4 & 00 & 40 \\
\hline 4 & 22 & 80 & 48 & 64 & 17 \\
& 22 & & 4 & 00 & 60 \\
\hline 5 & 22 & 60 & 48 & 36 & 13 \\
& 22 & & 4 & 00 & 20 \\
\hline 6 & 22 & 80 & 48 & 64 & 17 \\
& 22 & & 4 & 00 & 60 \\
\hline 7 & 22 & 60 & 48 & 36 & 13 \\
& 22 & & 4 & 00 & 20 \\
\hline 8 & 22 & 80 & 48 & 64 & 17 \\
& 22 & & 4 & 00 & 60 \\
\hline 9 & 22 & 70 & 48 & 49 & 15 \\
\hline
\end{tabular}

\begin{tabular}{|c|c|c|c|c|c|}
\hline & & & 4 & 00 & 40 \\
\hline 10 & 22 & 70 & $\begin{array}{c}48 \\
4\end{array}$ & $\begin{array}{l}49 \\
00\end{array}$ & $\begin{array}{l}15 \\
40\end{array}$ \\
\hline 11 & 22 & 80 & $\begin{array}{c}48 \\
4\end{array}$ & $\begin{array}{l}64 \\
00\end{array}$ & \begin{tabular}{|l}
17 \\
60
\end{tabular} \\
\hline 12 & 22 & 60 & $\begin{array}{c}48 \\
4\end{array}$ & $\begin{array}{l}36 \\
00\end{array}$ & $\begin{array}{l}13 \\
20 \\
\end{array}$ \\
\hline 13 & 22 & 70 & $\begin{array}{c}48 \\
4\end{array}$ & $\begin{array}{l}49 \\
00\end{array}$ & \begin{tabular}{|l}
15 \\
40
\end{tabular} \\
\hline 14 & 22 & 70 & $\begin{array}{c}48 \\
4\end{array}$ & $\begin{array}{l}49 \\
00\end{array}$ & \begin{tabular}{|l}
15 \\
40
\end{tabular} \\
\hline 15 & 22 & 80 & $\begin{array}{c}48 \\
4\end{array}$ & $\begin{array}{l}64 \\
00\end{array}$ & \begin{tabular}{|l}
17 \\
60
\end{tabular} \\
\hline 16 & 22 & 70 & $\begin{array}{c}48 \\
4\end{array}$ & $\begin{array}{l}49 \\
00\end{array}$ & \begin{tabular}{|l}
15 \\
40
\end{tabular} \\
\hline 17 & 22 & 80 & $\begin{array}{c}48 \\
4\end{array}$ & $\begin{array}{l}64 \\
00\end{array}$ & $\begin{array}{l}17 \\
60\end{array}$ \\
\hline 18 & 22 & 60 & $\begin{array}{c}48 \\
4\end{array}$ & $\begin{array}{l}36 \\
00\end{array}$ & $\begin{array}{l}13 \\
20\end{array}$ \\
\hline 19 & 22 & 80 & $\begin{array}{c}48 \\
4\end{array}$ & $\begin{array}{l}64 \\
00\end{array}$ & $\begin{array}{l}17 \\
60\end{array}$ \\
\hline 20 & 22 & 90 & $\begin{array}{c}48 \\
4\end{array}$ & $\begin{array}{l}81 \\
00\end{array}$ & $\begin{array}{l}19 \\
80\end{array}$ \\
\hline 21 & 22 & 60 & $\begin{array}{c}48 \\
4\end{array}$ & $\begin{array}{l}36 \\
00\end{array}$ & $\begin{array}{l}13 \\
20\end{array}$ \\
\hline 22 & 24 & 70 & $\begin{array}{r}57 \\
6\end{array}$ & $\begin{array}{l}49 \\
00\end{array}$ & $\begin{array}{l}16 \\
80\end{array}$ \\
\hline 23 & 23 & 70 & $\begin{array}{c}52 \\
9\end{array}$ & $\begin{array}{l}49 \\
00\end{array}$ & \begin{tabular}{|l}
16 \\
10
\end{tabular} \\
\hline 24 & 25 & 80 & $\begin{array}{c}62 \\
5\end{array}$ & $\begin{array}{l}64 \\
00\end{array}$ & $\begin{array}{l}20 \\
00\end{array}$ \\
\hline 25 & 24 & 80 & $\begin{array}{r}57 \\
6\end{array}$ & $\begin{array}{l}64 \\
00\end{array}$ & $\begin{array}{l}19 \\
20\end{array}$ \\
\hline 26 & 24 & 90 & $\begin{array}{c}57 \\
6\end{array}$ & $\begin{array}{l}81 \\
00\end{array}$ & $\begin{array}{l}21 \\
60\end{array}$ \\
\hline 27 & 23 & 70 & $\begin{array}{c}52 \\
9\end{array}$ & $\begin{array}{l}49 \\
00\end{array}$ & \begin{tabular}{|l}
16 \\
10
\end{tabular} \\
\hline 28 & 22 & 80 & $\begin{array}{c}48 \\
4\end{array}$ & $\begin{array}{l}64 \\
00\end{array}$ & $\begin{array}{l}17 \\
60\end{array}$ \\
\hline 29 & 24 & 90 & $\begin{array}{c}57 \\
6 \\
\end{array}$ & $\begin{array}{l}81 \\
00\end{array}$ & $\begin{array}{l}21 \\
60\end{array}$ \\
\hline 30 & 25 & 60 & $\begin{array}{c}62 \\
5\end{array}$ & $\begin{array}{l}36 \\
00\end{array}$ & $\begin{array}{l}15 \\
00\end{array}$ \\
\hline 31 & 23 & 70 & $\begin{array}{c}52 \\
9\end{array}$ & $\begin{array}{l}49 \\
00\end{array}$ & $\begin{array}{l}16 \\
10\end{array}$ \\
\hline 32 & 24 & 80 & 57 & 64 & \begin{tabular}{|l|l}
19 \\
\end{tabular} \\
\hline
\end{tabular}




\begin{tabular}{|c|c|c|c|c|c|}
\hline & & & 6 & 00 & 20 \\
\hline \multirow[t]{2}{*}{33} & \multirow{2}{*}{24} & 80 & 57 & 64 & 19 \\
\hline & & & 6 & 00 & 20 \\
\hline \multirow[t]{2}{*}{34} & \multirow{2}{*}{25} & 80 & 62 & 64 & 20 \\
\hline & & & 5 & 00 & 00 \\
\hline \multirow[t]{2}{*}{35} & \multirow{2}{*}{24} & 90 & 57 & 81 & 21 \\
\hline & & & 6 & 00 & 60 \\
\hline \multirow[t]{2}{*}{36} & \multirow{2}{*}{25} & 80 & 62 & 64 & 20 \\
\hline & & & 5 & 00 & 00 \\
\hline \multirow[t]{2}{*}{37} & \multirow{2}{*}{24} & 90 & 57 & 81 & 21 \\
\hline & & & 6 & 00 & 60 \\
\hline \multirow[t]{2}{*}{38} & \multirow{2}{*}{23} & 80 & 52 & 64 & 18 \\
\hline & & & 9 & 00 & 40 \\
\hline \multirow[t]{2}{*}{39} & \multirow{2}{*}{24} & 90 & 57 & 81 & 21 \\
\hline & & & 6 & 00 & 60 \\
\hline \multirow[t]{2}{*}{40} & \multirow{2}{*}{25} & 80 & 62 & 64 & 20 \\
\hline & & & 5 & 00 & 00 \\
\hline \multirow[t]{2}{*}{41} & \multirow{2}{*}{23} & 70 & 52 & 49 & 16 \\
\hline & & & 9 & 00 & 10 \\
\hline \multirow[t]{2}{*}{42} & \multirow{2}{*}{21} & 80 & 44 & 64 & 16 \\
\hline & & & 1 & 00 & 80 \\
\hline \multirow[t]{2}{*}{43} & \multirow{2}{*}{22} & 90 & 48 & 81 & 19 \\
\hline & & & 4 & 00 & 80 \\
\hline \multirow[t]{2}{*}{44} & \multirow{2}{*}{23} & 70 & 52 & 49 & 16 \\
\hline & & & 9 & 00 & 10 \\
\hline \multirow[t]{2}{*}{45} & & 90 & 62 & 81 & 22 \\
\hline & 25 & & 5 & 00 & 50 \\
\hline 46 & 22 & 70 & 48 & 49 & 15 \\
\hline & 22 & & 4 & 00 & 40 \\
\hline 47 & 21 & 80 & 44 & 64 & 16 \\
\hline & 21 & & 1 & 00 & 80 \\
\hline 48 & & 80 & 52 & 64 & 18 \\
\hline & 23 & & 9 & 00 & 40 \\
\hline 49 & 22 & 90 & 48 & 81 & 19 \\
\hline & $\angle 2$ & & 4 & 00 & 80 \\
\hline 50 & 21 & 70 & 44 & 49 & 14 \\
\hline & 21 & & 1 & 00 & 70 \\
\hline 50 & 11 & 38 & 25 & 29 & 86 \\
\hline & 38 & 00 & 97 & 32 & 68 \\
\hline & & & 4 & 00 & 0 \\
\hline $\mathrm{N}$ & $=\Sigma$ & $=\Sigma$ & $=$ & $=\Sigma$ & $=$ \\
\hline & $X$ & $\mathrm{Y}$ & $\underset{2}{\Sigma x}$ & $\mathrm{y}^{2}$ & $\Sigma \mathrm{x}$ \\
\hline
\end{tabular}

Dari tabel kerja diatas diperoleh

$$
\begin{aligned}
\Sigma \mathrm{X} & =1.138 \\
\Sigma \mathrm{Y} & =3.800 \\
\Sigma \mathrm{x}^{2} & =25.974 \\
\Sigma \mathrm{y}^{2} & =293.200 \\
\Sigma \mathrm{xy} & =86.680
\end{aligned}
$$

Selanjutnya masukkan angka-angka yang telah diperoleh kedalam rumus

$r_{x y}$

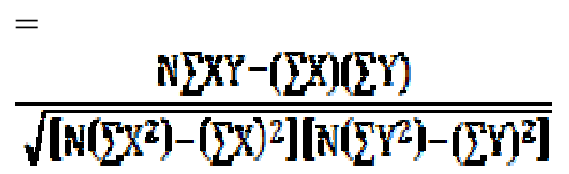

$r_{x y}$

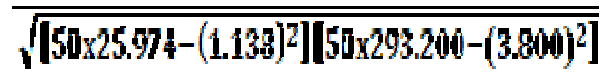

r

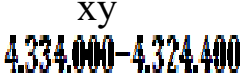

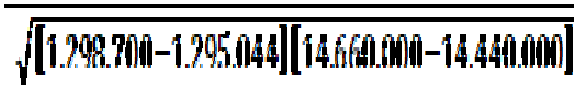

$r_{x y}$

$$
\begin{aligned}
& 55=2
\end{aligned}
$$

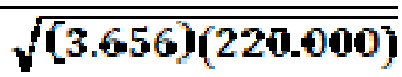

$$
\begin{aligned}
& r_{x y}=\frac{962}{925.322592} \\
& r_{x y}=\frac{35355596}{25355} \\
& r_{x y}=0,33849854 \\
& r_{x y}=0,34
\end{aligned}
$$

Berdasarkan hasil dari data perhitungan dan analisa data yang telah dilakukan, penulis menginterpretasikan hasil perhitungan diatas dengan menggunakan dua cara yang akan ditempuh sebagai berikut: 
1. Interpretasi

secara

kasar/sederhana dari hasil perhitungan di atas diperoleh nilai koefisien korelasi rxy yaitu 0,34 jika diperhatikan maka angka indeks korelasi positif, ini berarti korelasi antara variabel X (minat dalam bidang studi SKI) dan variabel Y (prestasi belajar SKI) terdapat hubungan searah, dengan istilah lain terdapat korelasi yang positif. Kemudian nilai tersebut diinterpretasikan dengan cara sederhana yaitu dengan memberikan interpretasi terhadap angka koefisien korelasi Product Moment. Apabila diperhatikan besarnya rxy yang telah diperoleh $(0,34)$ ternyata terletak antara 0,200 0,400 berarti antara variabel $\mathrm{X}$ dan variabel $\mathrm{Y}$ terdapat korelasi yang lemah atau rendah.

2. Interpretasi dengan menggunakan tabel nilai Product Moment:

Pertama : Merumuskan hipotesa alternatif ( $\mathrm{Ha})$ dengan hipotesa nihil (Ho). $\mathrm{Ha}=\mathrm{ada}$ atau terdapat korelasi positif atau terdapat korelasi negatif yang signifikan atau menyakinkan antara variabel $\mathrm{X}$ dan variabel $\mathrm{Y} . \mathrm{Ho}=$ tidak ada tidak terdapat korelasi positif atau korelasi negatif yang signifikan antara variabel $\mathrm{X}$ dan Y.

Kedua : Mencari degree off reedom (df) atau derajat bebas (db) adapun rumusnya sebagai berikut:

$$
\text { Df }=\mathrm{N}-\mathrm{n}
$$

Keterangan:

df : degree off reedom

$\mathrm{N}$ : Number of cases

$\mathrm{Nr}$ : Banyaknya variabel yang dikorelasik

Penelitian ini menggunakan teknik populasi yang mana seluruh siswa kelas $\mathrm{X}$ dan $\mathrm{XI}$ yang berjumlah 50. Variabel yang dikorelasikan sebanyak dua buah yaitu minat siswa mempelajari bidang studi SKI dengan hasil belajar SKI. Jadi $\mathrm{nr}=2$ dengan rumus diatas, maka diperoleh nilai $\mathrm{df}=50-2$ $=48$.

Ketiga : Berkonsultasi pada tabel Product Moment pada taraf signifikansi. Apabila rxy sama besar atau lebih besar pada $r$ tabel atau rt, maka hipotesa alternatif (Ha) diterima, karena teruji kebenarannya dan hipotesa nihil (Ho) ditolak. Namun apabila rxy lebih kecil dari pada $r$ tabel atau rt, maka hipotesa alternatif (Ha) ditolak dan hipotesa nihil (Ho) diterima, karena teruji kebenarannya. Dengan melihat tabel Product Moment, maka dapat diketahui bahwa dengan df sebesar 48 diperoleh Product Moment pada taraf signifikan 5\%=0,284.

Keempat : Membandingkan besarnya rxy dengan $\mathrm{rt}$, nilai rxy yang diperoleh adalah 0.34 , sedangkan pada nilai $\mathrm{rt}$ pada taraf signifikan $5 \%=$ 0,284 . Ternyata nilai re dari 
perhitungan 0,34 lebih besar dari pada nilai rt, pada taraf signifikan 5\%. Maka hipotesa alternatif (Ha) diterima dan hipotesa nihil (Ho) ditolak.

Dari hasil di atas dapat mengambil suatu pengertian tersendiri bahwa tinggi rendahnya prestasi belajar siswa dalam bidang studi SKI ada hubungannya dipengaruhi oleh tinggi rendahnya minat siswa dalam bidang studi SKI.

\section{Kesimpulan}

Berdasarkan dari hasil penelitian dan analisa yang penulis uraikan dalam bab IV mengenai hubungan antara minat belajar dengan prestasi belajar siswa dalam bidang studi SKI, maka dapat ditarik kesimpulan bahwa ada hubungan antara minat belajar dengan prestasi belajar siswa dan berdasarkan hasil perhitungan penelitian maka hubungan antara minat belajar dengan prestasi belajar terdapat korelasi yang lemah dan rendah dalam bidang studi SKI di Madrasah Aliyah Miftahul Ranurejo Sumberanyar Banyuputih Situbondo Tahun Pelajaran 2014/2015.

\section{Daftar Pustaka}

Zuhairi Misrawi, Revitalisasi islam" Supriyadi, A., Patmawati, F., \& Waziroh, I. (2023). STRATEGI PEMBELAJARAN EKSPOSITORI UNTUK ANAK BERKEBUTUHAN KHUSUS JENIS TUNARUNGU PADA MATA PELAJARAN PENDIDIKAN AGAMA ISLAM. Edupedia: Jurnal Studi Pendidikan dan Pedagogi Islam, 7(2), 177-188.

Hosaini, H. (2020). Pembelajaran dalam era "new normal" di pondok pesantren Nurul Qarnain Jember tahun 2020. LISAN AL-HAL: Jurnal Pengembangan Pemikiran dan Kebudayaan, 14(2), 361-380.

Samsudi, W., \& Hosaini, H. (2020). Kebijakan Sekolah dalam Mengaplikasikan Pembelajaran Berbasis Digital di Era Industri 4.0. Edukais: Jurnal Pemikiran Keislaman, 4(2), 120-125.

Mahtum, R., \& Zikra, A. (2022, November). Realizing Harmony between Religious People through Strengthening Moderation Values in Strengthening Community Resilience After the Covid 19 Pandemic. In The 4th International Conference on University Community Engagement (ICON-UCE 2022) (Vol. 4, pp. 293-299).

Hosaini, H., \& Samsudi, W. (2020). Menakar Moderatisme antar Umat Beragama di Desa Wisata Kebangsaan. Edukais: Jurnal Pemikiran Keislaman, 4(1), 1-10.

Hosaini, H., \& Kurniawan, S. (2019). Manajemen Pesantren dalam Pembinaan Umat. Edukais: Jurnal Pemikiran Keislaman, 3(2), 82-98.

Muis, A., Eriyanto, E., \& Readi, A. (2022). Role of the Islamic Education teacher in the Moral Improvement of Learners. AtTarbiyat: Jurnal Pendidikan Islam, 5(3).

Halim, A., Hosaini, H., Zukin, A., \& Mahtum, R. (2022). PARADIGMA ISLAM MODERAT DI INDONESIA DALAM MEMBENTUK PERDAMAIAN DUNIA. JISMA: Jurnal IImu Sosial, Manajemen, dan Akuntansi, 1(4), 705-708. 
Zukin, A., \& Firdaus, M. (2022). Development Of Islamic Religious Education Books With Contextual Teaching And Learning. AtTarbiyat: Jurnal Pendidikan Islam, 5(1).

Hosaini, H., Zikra, A., \& Muslimin, M. (2022). EFFORTS TO IMPROVE TEACHER'S PROFESSIONALISM IN THE TEACHING LEARNING PROCESS. Al-Risalah: Jurnal Studi Agama dan Pemikiran Islam, 13(2), 265-294.

Salikin, H., Alfani, F. R., \& Sayfullah, H. (2021). Traditional Madurese Engagement Amids the Social Change of the Kangean Society. RETORIKA: Jurnal IImu Bahasa, 7(1), 32-42.

Hosaini, H., \& Fikro, M. I. (2021). PANCASILA SEBAGAI WUJUD ISLAM RAHMATAN LI ALALAMIIN. Moderation/ Journal of Islamic Studies Review, 1(1), 9198.

Hosaini, H. (2020). Ngaji Sosmed Tangkal Pemahaman Radikal melalui Pendampingan Komunitas Lansia dengan sajian Program Ngabari di Desa Sukorejo Sukowono Jember. As-Sidanah: Jurnal Pengabdian Masyarakat, 2(1), 159-190.

Agustin, Y. D., Hosaini, H., \& Agustin, L. (2021). ANALYSIS OF THE IMPACT OF EARLY MARRIAGE ON ADOLESCENT REPRODUCTIVE HEALTH BASED ON HEALTH PERSPECTIVES AND ISLAMIC RELIGION. UNEJ e-Proceeding, 103-107.
Hosaini, H., \& Kamiluddin, M. (2021). Efektivitas Model Pembelajaran Means-Ends Analysis (MEA) dalam meningkatkan Keterampilan Komunikasi Interpersonal dan Pemecahan Masalah pada mata pelajaran Fikih. Edukais: Jurnal Pemikiran Keislaman, 5(1), 43-53.

Hosaini, H. (2020). PEMBELAJARAN DALAM ERA "NEW NORMAL" DI PONDOK PESANTREN NURUL QARNAIN JEMBER TAHUN 2020. LISAN AL-HAL: Jurnal Pengembangan Pemikiran dan Kebudayaan, 14(2), 361-380.

Hosaini, H. (2019). Behauvioristik Basid Learning Dalam Bingkai Pendidikan Islam Perspektif AlGhazali:(Pembelajaran Berbasis Prilaku Dalam Pandangan Pendidikan Islam). Edukais: Jurnal Pemikiran Keislaman, 3(1), 23-45.

Muslimin, M., \& Hosaini, H. (2019). KONSEP PENDIDIKAN ANAK MENURUT ALQUR'AN DAN HADITS. Edupedia: Jurnal Studi Pendidikan dan Pedagogi Islam, 4(1), 67-75.

Hosaini, H., \& Erfandi, E. (2017). Studi Komparasi Konsep Pendidikan Karakter Menurut KH. Hasyim Asy'ari dan Ki Hadjar Dewantara. Edukais: Jurnal Pemikiran Keislaman, 1(1), 136.

Agustin, L., Rahayu, L. P., Hosaini, H., Agustin, Y. D., \& Utami, C. B. (2022). Penyuluhan Kesehatan Reproduksi pada Remaja dalam Perspektif Kesehatan dan Hukum. DEDICATION: Jurnal Pengabdian Masyarakat, 2(2), 16-21. 